\title{
Analysis of Students' Arabic Proficiency for Vocabulary Mastery in State Islamic Junior High School in Muaro Jambi
}

\author{
Wahyudi Buska \\ Fakultas Adab dan Humaniora UIN Sulthan Thaha Saifuddin Jambi \\ E-mail: wahyudi@uinjambi.ac.id \\ Yogia Prihartini \\ Fakultas Tarbiyah dan Keguruan UIN Sulthan Thaha Saifuddin Jambi \\ E-mail: yogai_prihartini@uinjambi.ac.id \\ Nur Hasnah \\ Fakultas Tarbiyah dan Keguruan IAIN Bukit Tinggi \\ E-mail: hasnah_also@yahoo.com
}

\begin{abstract}
Abstrak: Mempelajari kosakata berarti menguasai kosakata, terjemahannya, dan penggunaannya dalam kalimat yang benar. Mampu menghafal kosakata tanpa tahu bagaimana menggunakannya dalam percakapan nyata tidak cukup. Dengan demikian, dalam praktiknya, siswa yang sudah memiliki cukup kosa kata diajarkan bagaimana menerapkannya secara tertulis atau lisan. Penelitian ini bertujuan untuk mengetahui bagaimana kosakata diajarkan dan seberapa efektif kosakata itu dalam meningkatkan kemahiran berbahasa Arab siswa di Madrasah Tsanawiyah Negeri (MTsN) Jaluko, Muaro Jambi. Peneliti menggunakan analisis data kualitatif dan kuantitatif di lapangan. Metode yang diterapkan adalah observasi; lebih khusus lagi, Pengamatan Langsung di mana peneliti secara langsung mengamati subyek sementara juga melakukan dokumentasi, tes tertulis dan lisan, dan wawancara. Peneliti menemukan bahwa studi kosa kata di MTsN Jaluko menggunakan beberapa metode pengajaran, beberapa di antaranya adalah metode pengajaran langsung, metode pengajaran tata bahasa, metode terjemahan, metode membaca, dan metode fonetik. Beberapa teknik yang digunakan adalah mendengarkan kata, spasi kata, pemahaman kata, membaca kata, menulis kata, dan membuat kata. Model pelatihan yang digunakan di MTsN Jaluko Muaro Jambi adalah praktik pola, praktik percakapan, drama, pidato. Materi pemahaman kosakata yang digunakan di MTsN Jaluko Muaro Jambi adalah pidato, mufradat dan struktur kata, bahan bacaan dan Insya 'Muwajjah. Untuk meningkatkan kemahiran berbahasa Arab Siswa MTsN Jaluko, sekolah menerapkan dua program; Iqro 'dan disiplin bahasa.
\end{abstract}

Kata-kata kunci: kemahiran berbahasa Arab; penguasaan kosakata; MTsN Muaro Jambi.

\footnotetext{
Abstract: Learning vocabulary means mastering vocabulary, its translation, and its use in the correct sentences. Being able to memorize vocabularies without knowing how to use it in real conversation is not enough. As such, in practice, students who already have enough vocabularies were taught how to implement it in written or spoken of. This research aims to find out how the vocabulary was taught and how effective it is in improving the students' Arabic proficiency at State Islamic Junior High School or Madrasaah Tsanawiyah Negeri (MTsN) in Jaluko, Muaro Jambi. The researcher used qualitative and quantitative data analysis in the field. The implemented method was observation; more specifically,
} 
Direct Observation where the researcher directly observes the subjects while also doing the documentation, written and spoken test, and interviews. The researcher found out that the study of vocabulary in MTsN Jaluko uses several teaching methods, some of them are direct teaching method, grammar teaching method, translation method, reading method, and phonetic method. Several techniques used were word listening, word spacing, word understanding, word reading, word writing, and word making. The training model used in MTsN Jaluko Muaro Jambi was pattern practice, conversation practice, drama, speech. Vocabulary comprehension material used in MTsN Jaluko Muaro Jambi were speech, mufradat and word structure, reading material and Insya' Muwajjah. In order to improve the Arabic proficiency of MTsN Jaluko's Students, the school implements two programs; Iqro' and language discipline.

Keywords: Arabic proficiency; vocabulary mastery; MTsN Jaluko Muaro Jambi.

\section{Introduction}

Language is a means of communication between humans in order to deliver what they mean. A group will tell another group about what they want using a language ${ }^{1}$. As such, language is something that must be learned and practiced in interacting with others ${ }^{2}$. Arabic and English are two of the most common language in the world to be used in social interaction ${ }^{3}$. As such, learning Arabic and English as language of communication needs to be intensified.

Learning Arabic is different than learning one's native language, that's why the learning principal must be different, whether it concerns the method, material, or the learning process. The Arabic proficiency fields include the ability to listen (listening competence/ mahaarah al-Istima), the skill to speak (speaking competence/ mahaarah al-takallum), the skill to read (reading competence/ mahaarah al-qira'ah), and the skill to write (writing competence/mahaarah al Kitaabah). Arabic is one of the foreign language which have spread considerably in several countries and regions ${ }^{4}$. The process of spreading Arabic language was mainly due to the expansion of Islam, where Islam used the foundation of Qur'an and Sunnah, both of which is in Arabic.

That is why the study of a language needs to be compiled in a way so that the aim goal is fulfilled. Those goals include: a).The students can understand Qur'an and Hadist as the foundation of Islam, b).The students can understand books about religion and culture written in Arabic. c).The students can speak and write in Arabic. d).The students can use their Arabic skill to help their daily life. e).To develope Arabic speaking students into professionals.

In Indonesia, Arabic is learned in Islamic schools from the elementary level to high school. The aim of teaching Arabic in MTsN Jaluko Muaro Jambi is so that the

\footnotetext{
${ }^{1}$ Jason Stanley. "Language as a Mechanism Of Control." In How Propaganda Works, (Princeton; Oxford: Princeton University Press, 2015).pp. 126

22 Daniel Cloud, "Meaning, Interpretation, and Language Acquisition." The Domestication of Language: Cultural Evolution and the Uniqueness of the Human Animal, (New York: Columbia University Press, 2015), pp. 183-202.

${ }^{3}$ Kees Versteegh. "Linguistic Contacts between Arabic and Other Languages." Arabica 48, no. 4 (2001): 470-508

${ }^{4}$ Anwar G. Chejne. The Arabic Language: It's Role in History. University of Minnesota Press, 1969. pp. 39
} 
students can understand language, whether through hearing or writing and be able to express their feelings whether through speaking or writing. The general aimoflearning Arabic is so that students can understand the Qur'an and understand the world's second most used language.

The biggest problem present is the lack of students' abilities in pronunciation of Arabic words, as well as the lack of knowledge of Arabic letters which makes learning Arabic not as effective ${ }^{5}$. The difficulties experienced by the students originated from their own lack of knowledge about Arabic since most of them originated from regular elementary school which doesn't teach Arabic at all. Furthermore, even though some students originated from Islamic elementary school, not all of them are proficient in speaking Arabic.

Arabic is viewed by the majority of students as a difficult and scary subject, which is proven by the low rate of score in Arabic subject compared to other subjects. This is a challenge wchich needs to be overcome by all juior high schools, especially in MTsN Jaluko Muaro Jambi. That is why the researcher was motivated to further study the Arabic proficiency of students in MTsN Jaluko Muaro Jambi.

\section{Arabic Proficiency and Vocabulary Learning Techiques}

Ability means the capacity to be able to do something. Competence is the capacity to move, think, and act consistently as a proof one's knowledge and skill. One important aspect in behavior is the ability to communicate with others. When one think about communication in general, the first thing that comes to mind is language. Mustaqim further states that language is an accurate communication tool for humans, to deliver either their thoughts, feelings, experience, or ideas. In order for those things to be communicated and understood by others correctly, a user needs to understand the rules of the language. ${ }^{6}$

Learning Arabic is different than learning one's native language, that's why the learning principal must be different, whether it concerns the method, material, or the learning process. The Arabic proficiency fields include the ability to listen (listening competence/mahaarah al-Istima), the skill to speak (speaking competence/mahaarah al-takallum), the skill to read (reading competence/ mahaarah al-qira'ah), and the skill to write (writing competence/ mahaarah al Kitaabah).

A study about human language is important for cognitive psychology, since: 1). Human development in using language gives a picture of unique abstraction of their connection with cognitive process. Humans have the highest level of language abstraction. 2). Language process is important for information storing and processing. 3). Human thinking process and problem-solving involves language. 4). Language the highest level of importance when trying to exchange information. 5). Language affects perception which is an important aspect of cognitive process. 6).

5 Jasmin Zine. "The Politics of Teaching and Learning in Islamic Schools." In Canadian Islamic Schools: Unravelling the Politics of Faith, Gender, Knowledge, and Identity, (Toronto; Buffalo; London: University of Toronto Press, 2008), pp.261-306..

${ }^{6}$ John M. Wiemann and Philip Backlund. "Current Theory and Research in Communicative Competence." Review of Educational Research, vol. 50, no. 1, 1980, pp. 185-199. 
Word processing, speaking, and semantics use the brain's cerebral area, which proves a strong connection between neurotic anatomy with language, such as in the case of Aphasic (a brain disorder resulting in the inability to process words).

From explanations above it can be concluded that learning Arabic is important, and language process is an important part of communication, as well as communicating in arabic. As such the ability to speak in Arabic must come first in learning Arabic. In learning Arabic there are three rules that must be paid attention to:

1. The rule of readiness, the higher a student's readiness, the easier for them to receive stimulus and responds to them. Readiness in influenced by one's nervous system. That is why the students need to be conditioned before the learning process begins.

2. The rule of practice. The connection between stimulus and response will strengthen if the connection is practiced often.

3. The rule of effect, this means that the connection between stimulus and response will happen if that connection develops favorable result.

From the rules above we can see that in an attempt to learn a language the pronunciation and repetition of words is essential in improving one's skill, especially in learning a foreign language. With a proper training and conditioning in learning Arabic, a good connection between stimulus and response will be developed. A study of Arabic will always be connected to the study of the Qur'an. This is because the fact that the Qur'an was written in Arabic. Arabic is often times referred to as the language of the Qur'an, which gives the impression that Arabic is a language of religion. People who speak about Islam will speak about the Qur'an which, in turn, is Arabic.

\section{a. The Definition of Vocabulary}

Vocabulary is everything that comes from words, gestures, speech, expression and a union of sounds which contains a meaning. Arabic is one of the foreign languages often taught in Indonesia. As such, the existence of a suitable learning method and material is important for non-arabic people. ${ }^{7}$ The study of Arabic can be done in various ways and methods, as well as learning vocabularies (al-mufradât).

Vocabulary is an important element that must be mastered by every foreign language learners. Owning a wide array of vocabulary will help people in communicate and write using a language.as such it can be said that the skill of a speaker is determined by a productive, actual, and rich mastery of vocabulary.

One's vocabulary is defined as the collection of one's words which they understand and are able to form new words with. The amount of someone's vocabulary is seen as their level of intelligence or education. ${ }^{8}$

From the description above we can conclude that vocabulary is a collection of words which form a language known by someone and can be used to make a

\footnotetext{
${ }^{7}$ Yongqi Gu and Robert Keith Johnson. "Vocabulary learning strategies and language learning outcomes." Language learning 46, no. 4 (1996): 643-679.

${ }^{8}$ Martha Rapp Haggard. "The vocabulary self-collection strategy: Using student interest and world knowledge to enhance vocabulary growth." Journal of Reading 29, no. 7 (1986): 634-642.
} 
new sentence or communicate with others. A proper use of vocabularies in a communication will give a picture of the user's level of intelligence.

In the study of vocabularies there are several things that must be paid attention to:

1. Vocabulary learning (al-mufradât) does not stand all by itself. Vocabulary (almufradât)must not be taught by itself, instead it must be taught with close connection with the study of muthâla'ah, istimâ', insyâ', andmuhâdatsah.

2. Limting the meaning. In learning vocabularies, the meaning of words need to be reduced to its sentence context only, considering the fact that a word may have more than one meaning. For beginners, it is recommended to teach them a suitable meaning of a word in a context so that their memory and attention will not be divided. For advanced level however, the explanation of meaning can be improved with wider understanding about the intended word.

3. Vocabulary within context. Some words in Arabic can't be understood without knowing how it is used in a sentence. Words such as this needs to be taught in a contextual format so as not to cause any misunderstanding between students.

4. Translation in vocabulary learning. Learning vocabularies by translating them into one's native language is the easiest method, but present several weaknesses. One of them is that it could reduce the students' spontaneity when trying to use those words during a communication process. It also present difficulty when faced with nouns, is difficult to remember, and at last not all of those words can be correctly translated into their native tongue. As such, translation method should be used as a last measure in learning vocabularies, when there are abstract words or words that can't be practically acted in order to understand its meaning.

\section{b. The Meaning and Function of Vocabularies (al-Mufradât)}

Vocabularies as lexicon will be functional when it has a meaning. The meaning of words can be separated into denotative (إضافن) (أصلى). Dennotative (أصلى) meaning is comprised of literal and figurative meaning, original meaning and terminological meaning. Connotative meaning is an additional meaning given as the cause of language user's experiences. According to Arif etc, connotative meaning is one or a group of words which was based off of feelings or thinking that appeared for made appear on speaker and listener. ${ }^{9}$

\section{c. Vocabulary Learning Techniques and Methods (al-Mufradât)}

Learning methods are the techniques in delivering various learning materials to students which then used under suitable condition. Learning Arabic is no different. Learning Arabic vocabularies requires the existence of basic methods which can be utilized in every educational organization without the needs of overpriced

${ }_{9}$ Muhammad Zaenuddin Arif, Andi Haris Prabawa, and M. Hum. "Analisis Makna Denotatif Dan Konotatif Pada Tekslaporan Hasil Observasi Karangan Siswa Kelas VII Mts Negeri Surakarta II." PhD diss., Fakultas Keguruan dan Ilmu Pendidikan, 2016. 
facilities. Meanwhile, it's true that a proper facility will greatly improve the success of these methods.

In learning vocabularies, it is recommended to start by learning words that is hard to change its meaning, such as the names of family relationship, parts of body, pronouns, main verbs etc. The plausible methods include direct method, imitating and memorizing, reading, grammatical-translation, picture cards, and singing.Various techniques that can be used such as word play, comparison, word mashup, and using dictionaries are all pretty effective. ${ }^{10}$

Ahmad Fuad Effendy explains further the stages and techniques of learning vocabularies or the students' experience in knowing and acquiring word meaning, as follows:

1. Listening to words. This is the first step by giving the chance to students to listen the words spoken by teacher or other media, either by its own word or in a sentence. When the word have been mastered by the students, they will be able to listen to it again correctly in the furture

2. Pronouncing the words.In this step, the teacher will give a chance to the students to pronounce the words that they have listened to. Pronouncing new words will help students remember those words longer.

3. Acquiring the meaning of the words.In this step, the teacher should avoid translation in giving the meaning to students, since it will disturb the communication within the language, while the meaning of the words will be forgotten faster. There is a technique that can be used by teachers in avoiding the use of translation in order to acquire the meaning of a word, which is by giving sentence context, simple definition, the use of pictures, synonym (murâdif), antonym (dlid), showing a model, and body language.

4. Reading the words. After listening, pronouncing, and understanding the new vocabularies, the teacher will write them on the board. The students are then given a chance to read them out loud.

5. Writing the words. Students mastery of new vocabularies will be greatly enhanced when they're asked to write the words they just learned since their memorization of new words should be incredibly strong.

6. Making new sentence. The final step of the activity is using those words to make a proper sentence, either written or spoken. The teacher needs to be creative in giving example of various sentences and asked the students to imitate them. In forming those sentences, they're recommended to use an actual and productive sentences which can help them in their daily life. ${ }^{11}$

The steps or procedures in learning vocabularies above can be used as reference by foreign language teachers even though new words can be taught using other methods as well.Time allocation need to be taken into consideration as well. Difficult or special words that can only be understood within certain context must be filtered.

10 Chih-Ming Chen and Yi-Lun Li. "Personalised context-aware ubiquitous learning system for supporting effective English vocabulary learning." Interactive Learning Environments 18, no. 4 (2010): 341-364.

${ }^{11}$ Ahmad Fuad Effendy. "Metodologi Pengajaran Bahasa Arab." Malang: Misykat (2009). hlm. 21 
The word "language" has various definitions. Aside from saying that language is words spoken or written, language is also a means of communication for humans. Others defined language as nouns, verbs, sentences, expressions, and many others studies in schools. ${ }^{12}$ A language is a system of communication which consists of a set of sounds and written symbols which are used by the people of a particular country or region for talking or writing.

Language is a system of symbols using sounds that can be pronounciated and heard. Arabic have a special function compared to others. ${ }^{13}$ Arabic is not only a language that have a high literary value, but it is also a holy language used to communicate God's will. That is why it contains a value incomprehensible by humans. This is the undisputable fact of Arabic.

Arabic and the Qur'an is two different side of the same coin. Learning Arabic is a must for those who want to learn the Qur'an, and learning the language of the Qur'an means learning Arabic. As such, arabc does not only function as a mean of communication between humans, but also for humans to communicate with their God using prayers.

A happy news for us is during its development, Arabic had been formally decided as one of the world's international language. So it is no surprise that Arabic is heavily encouraged to be taught in educational organizations such as schools, whether it's a state school or a private school. This surely had been calibrated with students' general level of knowledge. In many institutions, Arabic had been a primary foreign language subject aside from English.

The kind of this research underlying this article is qualitative, but in order to acquire an optimal amount of data, researcher also did a library research to complete the data on the field.The populations in this research are the students of MTsN Jaluko Muaro Jambi. According to the official data from the school, there are 199 registered students in MTsN Jaluko during the 2017/2018 academic year.

Random sampling method was used in determining the samples (Kerlinger, 1995 : 192). Researcher only take 30\% of total subject as subjects, which is 8 people.Researcher used suitable form and methodsin order to acquire an authentic data. The ind and source of data in this research are: 1). Arabic teacher from $7^{\text {th }}$ grade of MTsN Jaluko Muaro Jambi, 2). Students from grate $7^{\text {th }}$ of MTsN Jaluko Muaro Jambi, 3). Documents from MtsN Jaluko.In collecting required data for this research, researcher used several methods:

\section{1) Interview}

Researcher used a semi-structured interview for data gathering, where the flexibility is more favorable than a structured interview. The aim of this interview is to find the problem in a more open way, where the informant was asked for their ideas and opinions. During the interview, researcher needs to listen carefully and make notes of the collected information.

\footnotetext{
12 Adrian Akmajian, Ann K. Farmer, Lee Bickmore, Richard A. Demers, and Robert M. Harnish. Linguistics: An introduction to language and communication. MIT press, 2017.

${ }^{13}$ George Yule. The study of language. Cambridge university press, 2016. pp.242
} 


\section{2) Observation}

Observation is viewed as systematical experience and recording towards the object of research. The observation that we do is by observing the learning process of Arabic subject in MTsN Jaluko Muaro Jambi.

\section{3) Documentation}

Documentation method is used to explore data histories. It can also be viewed as a way to collect data by collecting documents and notes which will help the research.After the data had been collected, they are analyzed. In a qualitative research, data analysis is done during the data collection process, and after the data collection process have finished for some time. There ara three activities in data analysis process; data reduction, data display, andconclution drawing/verification. All of those steps are interactive in nature.

During the reduction step, data will be categorized into more those that are important, meaningful, and relevant towards the research. After the data are reduced, the next step would be to display the data. In qualitative research, data display can be done in the form of short paragraph, tables, connection between categories, and any of the sorts. Miles and Huberman stated that a narrative text is most commonly used way in displaying a data. The third step in qualitative data analysis, according to Miles and Huberman, is drawing conclusion/verification. Conclusion in qualitative research is a newe finding that had never been found before. It could be a description or a picture of an obscure object.

\section{Arabic Education Process in MTsN Jaluko Muaro Jambi}

Madrasah Tsanawiyah Negeri (MTsN) is a formal Islamic school on the same level as junior high school. Aside from common junior high subjects, Madrasah Tsanawiyah also teach religious subjects, such as Arabic. According to General Rules of Teaching Program (GBPP) of Madrasah Tsanawiyah on page II of regulations from Indonesian Ministry of Religion, Number 372 22nd of December 1993, stated that arabic s one of the main subject in every MTs. Furthermore, Arabic also functions as language of religion and knowledge aside from being a mean of communication. That's why Arabic is an inseparable aspect of MTs and Islamic study as a whole.

Arabic becomes an important subject in every Islamic schools, because not only the Arabic that is taught is Arabic fusha, mastering Arabic will also help studentslearn the foundations of Islam, such as the Qur'an and the Hadith, as well as other books that is written in Arabic. In order for the Arabic study to be successful there must exists a general rule that dictates the materials to be learned, these rules is written in GBPP.

In Madrasah Tsanawiyah Jaluko Muaro Jambi, the study of Arabic has been done according to GBPP, where it is taught using 4 main materials in every focus. Those 4 materials are conversations, Mufradat and sentence structure, reading and Insya' Muwajjah (writing and creating sentences). These 4 main materials will be taught on every focus of study, with increasing level in difficulty according to grade. 
Meanwhile, the methods are adjusted with the subjects.

a. Conversation

this material used the direct method learning, which is the skill in speaking to change, deepen the Qawaid, the skill to write, the skill to read, the fluency of translation, so that the speaker can not only write their ideas, but are also able to express them out loud.

b. Mufradat and sentence structure

This material uses grammar-translation teaching method. The material consists of the memorization of sentence structure, translating words without context, translation of short reads, translation with context. Pronunciation practice is not given.

\section{c. Reading}

This material uses the reading method, which aims to teach and practice the skill of students in foreign language. Materials are divided into short sections. A list of words which meaning will be taught using context, translation, or pictures, is first introduced in these senctions. After reaching a certain level of ability, a new material in the form of short stories is added.

d. Insya' Muwajjah

This material used the phonetic teaching method. It is first done by giving hearing training, and then followed by pronouncing sounds, then words, and then a longer sentence. Those words are then connected into conversations and short stories. Materials are written in phonetic instead of normal spelling. Grammar is taught inductively, and free writing is based of words heard and read.

\section{The Arabic Proficiency of Students in MTsN Jaluko Muaro Jambi}

Arabic forced the students to have a skill in listening, speaking, reading, writing and composing. It will be difficult to learn Arabic if students can't even read Arabic letters.Especially if students does not originate from an Islamic elementary school, but from a normal school where Arabic is not a main subject. Having the student to be familiar with Arabic will drastically enhance the effectiveness of Arabic classes. As such, the fluency of reading Arabic becomes an important foundation for students who want to learn Arabic.

MTsN Jaluko Muaro Jambi, is a formal educational institution on the level of junior high school. Students learning in those schools are mostly graduate from elementary schools. As such, their background varies greatly. There are students who were originally planning to register on the MTs from the get go, but there are also those who are not accepted in a normal junior high school.

This wide variation in learning background creates a various background in Arabic proficiency. Students who were originally planning on entering MTsN are usually quite familiar with Arabic. On the other hand, those who are not accepted in normal school and entered MTsN have a lower level of proficiency in Arabic. Combining these students surely creates problems in class.

Even with GBPP in hand, having various level of students sitting in the same class will have a bad impact on the overall result. This happens especially 
during the early years of study. Students who are not familiar with Arabic will have a great difficulty learning Arabic, which then resulted in bad score. The difference in scores is surprising. Generally, in order to achieve the minimum score of 6 , great amount of effort is needed.

From the interview result, the low students' low score is affected by their lack of ability in reading Arabic letters. Only several students have a good reading ability. This means that the students' motivation in Arabic is dependent in their ability to read Arabic.

\section{Teacher's Effort in Improving Students' Arabic Proficiency in MTsN Jaluko}

In executing the study of Arabic in MTsN Jaluko Muaro Jambi, the students' level of proficiency become a special problem. The materials and lessons cant' be effectively learned by students due to their lack of vocabularies. In order to solve this problem, several efforts had been done by the teachers.

Efforts done must be effective and efficient since the ability to master vocabulary as soon as possible is an urgent matter. In other words, students need to be able to read Arabic in short time since it is the main qualifications of a successful Arabic class. Below is the result of researcher's interview with the headmaster of MTsN Jaluko Muaro Jambi.

The chool tried to include students who don't know how to read Arabic by including them in the Iqro' program. Iqro' is a quick method in learning Arabic letters. Before following the Iqro' program, students who registered will be given an Arabic proficiency test. It was done so that the school has general idea about students who know how to read Arabic and those who are not. From the result of this test, those who are deemed needy will be included in the program. This happens outside of formal school sessions.

This program is sponsored by the educational institution of MTsN Jaluko Muaro Jambi on the evening after Ashar prayer. This is a non-formal education specialized in studying religious subjects. All students who are not yet able to read Arabic is required to follow this program until they are considered proficient. With this program, the impact of students' lack in ability can be minimized.

Furthermore, students who are having trouble in speaking and reading is paid special attention to by the teacher. This is especially true concerning reading the letters. This effort also gives a significant advantage in solving the previous problems.

Even though the overall problem cannot be solved in an instant, these efforts by the teachers have helped lessen the negative impact. By using this program, the students' scores have proven to be increasing. During the first semester, students who didn't know how to read Arabic have low scores. Those who follow the Iqro' program have a significantly higher score in the second semester.In order to find out the result of the teachers' efforts, we can refer to the students' score on the next semester after the next exam. 


\section{Concluding Remarks}

Based on the result of research and data analysis stated above, the conclusion can be drawn as follows: (a) MTsN Jaluko Muaro Jambi has followed the GBPP in implementing and teaching Arabic language subject. (b) The vocabulary proficiency of the students in MTsN Jaluko Muaro Jambi is deemed lacking due to their low ability in reading Arabic letters. (c). The study of vocabulary in MTsN Jaluko uses several teaching methods, some of them are direct teaching method, grammar teaching method, translation method, reading method, and phonetic method (d) Several efforts in minimalizing the problems include by having students follow Iqro' program outside of formal study hours so that they can practice reading Arabic letters. (e) The training model used in MTsN Jaluko Muaro Jambi was pattern practice, conversation practice, drama, speech. Vocabulary comprehension material used in MTsN Jaluko Muaro Jambi were speech, mufradat and word structure, reading material and Insya' Muwajjah. In order to improve the Arabic proficiency of MTsN Jaluko's Students, the school implements two programs; Iqro' and language discipline.

\section{Bibliografi}

A. Chynthia Boardman. Writing to Communicate Paragraphs and Essays. Longman. San Fransisco. 2002

Abdul Aziz. Psikolinguistik Pembelajaran Bahasa Arab. Bandung: Humaniora. 2009

Abdul Wahab Rosyidi. Media Pembelajaran Bahasa Arab. Malang: UIN Malang. 2009

Acep Hermawan. Metodologi Pembelajaran Bahasa Arab. Bandung: PT Remaja Rosdakarya. 2011

Ahmad Fuad Effendy. "Metodologi Pengajaran Bahasa Arab." Malang: Misykat 2009

Ahmad Izzan. Metodologi Pembelajaran Bahasa Arab, Bandung: Humaniora. 2004

Akmajian, Adrian, Ann K. Farmer, Lee Bickmore, Richard A. Demers, and Robert M. Harnish. Linguistics: An introduction to language and communication. MIT press, 2017.

Anwar G. Chejne. The Arabic Language: Its Role in History. University of Minnesota Press, 1969

Azhar Arsyad. Bahasa Arab dan Metode Pengajarannya, Yogyakarta; Pustaka Belajar. 2004

Chaedar Al Wasilah. Pengajaran Bahasa komunikatif, Teori dan Praktek Bandung: Remaja Rosda Karya. 2000

Chih-Ming Chen and Yi-Lun Li. "Personalised context-aware ubiquitous learning system for supporting effective English vocabulary learning." Interactive Learning Environments 18, no. 42010 
Daniel Cloud. "Meaning, Interpretation, and Language Acquisition." The Domestication of Language: Cultural Evolution and the Uniqueness of the Human Animal, New York: Columbia University Press, 2015

George Yule. The study of language. Cambridge university press, 2016

H. Douglas Brown. Language Assessment: Principles and Classroom Practices. San Fransisco state University.2004

Jasmin Zine. "The Politics of Teaching and Learning in Islamic Schools." In Canadian Islamic Schools: Unravelling the Politics of Faith, Gender, Knowledge, and Identity, Toronto; Buffalo; London: University of Toronto Press, 2008

Jason Stanley. "Language as a Mechanism Of Control." In How Propaganda Works, Princeton; Oxford: Princeton University Press, 2015

John M. Wiemann and Philip Backlund. "Current Theory and Research in Communicative Competence." Review of Educational Research, vol. 50, no. 1, 1980

Kees Versteegh. "Linguistic Contacts between Arabic and Other Languages." Arabica 48, no. 42001

M. Abdul. Hamid. Mengukur Kemampuan Bahasa Arab. Malang: UIN Maliki Press. 2010

Martha Rapp Haggard. "The vocabulary self-collection strategy: Using student interest and world knowledge to enhance vocabulary growth." Journal of Reading 29, no. 71986

Muhammad Rajab. Pentingnya Pembelajaran Bahasa Arab, Malang: Persada.2008

Muhammad Zaenuddin Arif. Andi Haris Prabawa. "Analisis Makna Denotatif Dan Konotatif Pada Tekslaporan Hasil Observasi Karangan Siswa Kelas VII Mts Negeri Surakarta II." PhD diss., Fakultas Keguruan dan Ilmu Pendidikan, 2016.

Muhbib Abdul Wahab. Epistemologi dan Metodologi Pembelajaran Bahasa Arab. Jakarta: UIN Syarif Hidayatullah. 2008

Mursyadi. Percakapan Bahasa Arab-Indonesia- Inggris, Solo: As-Salam Publishing. 2010

Mustofa Ghulayani. Jami'uddurus Al'arobyah, Bairut Libanon: Al Maktabah Al'Ashriyyah. 2003

Suharsimi Arikunto. Manajemen Penelitian, Jakarta: Rineka Cipta. 2000

Syu'aib H. A. Tharaiq al-Tadris al-lughah al-Arabiyah, Beirut: Dar al-Ulum alArabiyah. 2011

Yayan Nurbayan. Metodologi Pembelajaran Bahasa Arab, Bandung : Zein Al-Bayan. 2008

Yongqi GU. and Robert Keith Johnson. "Vocabulary Learning Strategies and Language Learning Outcomes." Language learning 46, no. 41996. 